\title{
PERANAN ORANG TUA, LINGKUNGAN, DAN PEMBELAJARAN KEWIRAUSAHAAN TERHADAP KESIAPAN BERWIRAUSAHA
}

\author{
Monry Fraick Nicky Gillian Ratumbuysang \\ Universitas Lambung Mangkurat \\ light_4_avatar@yahoo.com \\ Aliyah A. Rasyid \\ Universitas Negeri Yogyakarta \\ aliyahrasyid@gmail.com
}

\begin{abstract}
Abstrak
Penelitian ini bertujuan untuk menemukan peranan orang tua, lingkungan, dan pembelajaran kewirausahaan terhadap kesiapan berwirausaha mahasiswa prodi Pend. Ekonomi, FKIP, Universitas Lambung Mangkurat Banjarmasin Kalimantan Selatan. Populasi penelitian adalah 162 orang mahasiswa Prodi Pend. Ekonomi FKIP Universitas Lambung Mangkurat Banjarmasin Kalimantan Selatan. Sampel sejumlah 110 mahasiswa ditentukan menggunakan teknik proportional random sampling. Dalam penelitian ini pendekatan yang digunakan adalah pendekatan kuantitatif. Sedangkan teknik yang digunakan adalah penelitian ex-post facto. Instrumen yang digunakan dalam penelitian ini adalah angket, untuk mengukur variabel pandangan orang tua, lingkungan, dan pembelajaran kewirausahaan. Hasil penelitian adalah sebagai berikut: 1) peranan orang tua tidak memiliki pengaruh positif terhadap kesiapan berwirausaha mahasiswa, yang ditunjukkan oleh besarnya nilai $p$ (sig) yaitu 0,339, di mana nilai $p>0,05$; maka hipotesis pertama yang diajukan ditolak; 2) lingkungan memiliki pengaruh positif terhadap kesiapan berwirausaha mahasiswa, yang ditunjukkan oleh besarnya nilai $p$ (sig) yaitu 0,000, di mana nilai $p<0,05$; maka hipotesis kedua yang diajukan diterima; 3) pembelajaran kewirausahaan memiliki pengaruh positif terhadap kesiapan berwirausaha mahasiswa, yang ditunjukkan oleh besarnya nilai p (sig) yaitu 0,000, di mana nilai $p<0,05$; maka hipotesis ketiga yang diajukan diterima; 4) pandangan orang tua, lingkungan, dan pembelajaran kewirausahaan secara bersama-sama memiliki peran positif terhadap kesiapan berwirausaha mahasiswa yang ditunjukkan oleh besarnya nilai p (sig) yaitu 0,000, di mana nilai $p$ $<0,05$; maka hipotesis keempat yang diajukan diterima.
\end{abstract}

Kata kunci: Peranan orang tua, lingkungan, pembelajaran kewirausahaan, dan kesiapan berwirausaha

\section{ROLES OF THE PARENTS, ENVIRONMENTS, AND ENTREPRENEURSHIP LEARNING ON THE ENTREPRENEURIAL READINESS}

Abstract

This study aims to investigate the roles of the parents, environments, and entrepreneurship learning, on the entrepreneurial readiness of the students of the Study Program of Economics Education, the Faculty of Teacher Training and Educational Sciences, the Lambung Mangkurat University, Banjarmasin, South Kalimantan. The population comprised the students of the Study Program of Economics Education, the Faculty of Teacher Training and Educational Sciences, the Lambung Mangkurat University, Banjarmasin, South Kalimantan totalling 162 student. The student sample is 110 people was selected by means of the proportional random sampling technique. The study employed the quantitative approach and the technique was ex post facto. The research instruments included questionnaires to measure the variables of the parents' perceptions, environments, and entrepreneurship learning. The results of the study are as follows. 1) The parents' roles do not have a positive effect on the students' entrepreneurial readiness, indicated by the value of $p$ (sig), 
namely 0.339, and $p>0.05$; therefore the first hypothesis is rejected. 2) The environments have a positive effect on the students' entrepreneurial readiness, indicated by the value of $p$ (sig), namely 0.000 , and $p<0.05$; therefore the second hypothesis is accepted. 3) The entrepreneurship learning has a positive effect on the students' entrepreneurial readiness, indicated by the value of $p$ (sig), namely 0.000, and $p<0.05$; therefore the third hypothesis is accepted. 4) The parents' perceptions, environments, and entrepreneurship learning as an aggregate have a positive effect on the students' entrepreneurial readiness, indicated by the value of $p$ (sig), namely 0.000, and $p<0.05$; therefore the fourth hypothesis is accepted.

Keywords: roles of parents, environments, entrepreneurship learning, entrepreneurial readiness

\section{PENDAHULUAN}

Pengangguran dan kemiskinan di Indonesia masih menjadi masalah klasik dari pembangunan. Perlambatan pertumbuhan ekonomi menjadi 5,92 persen di semester I 2013 dikhawatirkan akan berdampak pada bertambahnya tingkat angka pengangguran di Indonesia. Berdasarkan data Badan Pusat Statistik (BPS), jumlah pengangguran di Indonesia per Februari 2013 masih menunjukkan jumlah 7,17 juta orang dari total angkatan kerja yang mencapai 121,2 juta orang (5,92 persen). Sedangkan Tingkat Pengangguran Terbuka (TPT) di Indonesia pada Februari 2012 mencapai 120,4 juta orang, bertambah sekitar 3 juta orang dibanding angkatan kerja Agustus 2011 sebesar 117,4 juta orang (BPS, 2013).

Dalam kurun waktu beberapa tahun terakhir pemerintah memfokuskan program pembangunannya dengan upaya pengurangan pengangguran dan kemiskinan untuk peningkatan perekonomian. Upaya yang dilakukan adalah melaksanakan program padat karya, pengembangan wirausaha produktif dan memperbanyak pelaksanaan bursa kerja (job fair) oleh pemerintah dan swasta.

Dalam Rencana Pembangunan Jangka Menengah (RPJM) 2010-2014, tersurat pemerintah akan terus melanjutkan tiga strategi pembangunan ekonomi, yaitu pro growth, pro job dan pro poor. Termasuk di dalamnya mewujudkan pertumbuhan disertai pemerataan (growth with equity). Ketiga strategi itu diharapkan sebagai pendorong percepatan laju pertumbuhan ekonomi yang dapat memberikan lebih banyak kesempatan kerja. Dengan demikian, makin banyak keluarga Indonesia dapat menikmati hasil-hasil pembangunan dan dapat keluar dari kemiskinan (Depkeu, 2013).
Untuk mampu menciptakan lapangan kerja dan mengurangi kemiskinan, salah satu cara yang bisa dilakukan adalah perlu dikembangkannya karakter kewirausahaan sedini mungkin. Pada tahun 2007, jumlah wirausaha di Singapura ada sebesar 7,2\%, Amerika Serikat 2,14\%, Indonesia yang mana jumlah penduduk kurang lebih sebesar 220 juta, jumlah wirausahanya sebanyak 400.000 orang $(0,18 \%)$, seharusnya jumlah wirausaha di Indonesia sebesar 4.400 .000 orang. Karena suatu bangsa akan maju apabila jumlah wirausahanya paling sedikit $2 \%$ dari jumlah penduduk, berarti jumlah wirausaha di Indonesia kekurangan sebesar 4 juta orang. Sementara itu, Deputi Menteri Koperasi dan UKM bidang pengembangan SDM, Kemenkop \& UKM, mengatakan bahwa jumlah wirausaha Indonesia dari data terakhir bulan Maret 2012 melonjak tajam dari $0,24 \%$ menjadi $1,56 \%$ dari jumlah penduduk.

Kemenkop optimistis tahun 2014 pertumbuhan wirausaha ke titik ideal minimal 2\% dapat tercapai (Kemenkop, 2012). Bahkan menurut data BPS bulan Februari 2012, jumlah tenaga kerja yang memilih untuk berusaha sendiri masih relatif banyak yaitu sebesar 19,54 juta jiwa (BPS, 2013). Hal ini mengidentifikasikan bahwa berusaha sendiri atau berwiraswasta dapat menjadi alternatif lain dalam hal mengatasi pengangguran. Dari uraian di atas maka dapat disimpulkan bahwa solusi utama untuk mengatasi persoalan tersebut adalah dengan memberikan pendidikan kewirausahaan yang tidak hanya bersifat teoritis saja. Pendidikan kewirausahaan yang membentuk softskill dan mengasah hardskill masyarakat agar lebih jeli melihat peluang sehingga mereka siap dan benar-benar menjadi masyarakat pencipta lapangan pekerjaan bagi orang lain. 
Persepsi sebagian orang tua mengenai wirausaha sama dengan berdagang, yang jelas-jelas berbeda dari makna sesungguhnya wirausaha itu sendiri. Kurangnya pengetahuan orang tua mengenai makna sebenarnya dari kewirausahaan itu membuat pekerjaan sebagai seorang wirausaha menjadi sangat dihindari. Apalagi setelah melihat dan mendengar pengalaman buruk teman-teman mereka yang gagal dalam berwirausaha menjadikan mereka menutup diri akan hal-hal yang berbau wirausaha. Upaya melindungi anak-anaknya, orang tua sengaja menyekolahkan anakanaknya di jalur yang mereka anggap lebih banyak diperlukan dalam pemerintahan atau menjadi pegawai negeri.

Menurut Herdiman (Suharti \& Sirine, 2012, p.131), keluarga menjadi lingkungan pertama yang dapat menumbuhkan mental kewirausahaan anak. Pentingnya peranan keluarga dalam mendorong minat anak dalam berwirausaha diakui sebagian besar responden dalam penelitian yang dilakukan terhadap para mahasiswa peminat berwirausaha di Bandung (Isdianto $d k k$., 2005 dalam Suharti \& Sirine , 2012, p.131). Orangtua yang berprofesi sebagai wirausaha diyakini dapat menjadi panutan (entrepreneurial role model) yang akan membentuk minat anak untuk berwirausaha di masa depan (Dunn \& HoltzEakin, 2000; Galloway et al., 2006, dalam Suhati \& Sirine, 2012: 131). Dari uraian di atas dapat disimpulkan bahwa peranan orang tua ialah dorongan orang tua berupa pendapat terhadap sesuatu hal berdasarkan pengetahuan dan pengalaman yang dimilikinya yang berguna untuk memberikan masukan sehingga akhirnya mempengaruhi keputusan yang akan diambil.

Lingkungan menjadikan mereka lebih memilih pekerjaan kantor atau pekerjaan sebagai pegawai negeri dibandingkan menjadi wirausaha. Lingkungan dalam hal ini adalah lingkungan sosial, ialah semua yang orang/ manusia lain yang mempengaruhi kita (Purwanto, 2006, p.28). Pengaruh lingkungan sosial itu ada yang kita terima secara langsung dan ada yang tidak langsung. Pengaruh secara langsung, seperti dalam pergaulan seharihari dengan orang lain, dengan keluarga kita, teman-teman kita, kawan sekolah, lingkungan sepekerjaan dan sebagainya. Yang tidak langsung, melalui radio dan televisi, dengan membaca buku-buku, majalah-majalah, suratsurat kabar, dan sebagainya, dan dengan cara yang lain.

Dari uraian di atas maka dapat disimpulkan bahwa lingkungan yang mendukung pengembangan kreatifitas dan inovasi dari calon wirausaha sangat diperlukan. Lingkungan yang memberikan kesempatan mereka berkembang lebih baik lagi. Lingkungan yang menerima profesi wirausaha sebagai profesi yang tidak hanya bermanfaat bagi diri sendiri tetapi juga bagi orang lain.

Fakultas Keguruan dan Ilmu Pendidikan Universitas Lambung Mangkurat sebagai salah satu wadah pencetak calon guru di Kalimantan Selatan memiliki visi menjadi lembaga pendidikan tenaga kependidikan yang terkemuka yang lulusannya memiliki kemampuan akademik, profesional dan menguasai teknologi informasi serta daya saing yang tinggi (fkipunlam, 2013). Visi tersebut sejalan dengan pengertian pendidikan teknologi dan kejuruan menurut (Calhoun, 1982, p.2) bahwa pendidikan kejuruan adalah suatu program pendidikan yang menyiapkan individu peserta didik menjadi tenaga kerja yang profesional, juga siap untuk dapat melanjutkan ke jenjang yang lebih tinggi. Hal ini sejalan dengan pengertian dari Unesco (Unesco, 1973, p.11) bahwa pendidikan teknologi dan kejuruan haruslah menjadi bagian dari sistem pendidikan, memberikan pelatihan bagi individual yang bertujuan untuk menyediakan seseorang yang peduli dengan keahlian yang diperlukan dan pengetahuan berteori.

Misi Fakultas Keguruan dan Ilmu Pendidikan, salah satunya ialah menyelenggarakan pendidikan akademik dan profesional yang lulusannya menjadi tenaga kependidikan pada jenjang pendidikan dasar (TK, SD/MI, dan SMP/MTs, SMA/MA, SMK serta Pendidikan Tinggi) sesuai kebutuhan pengembangan pendidikan dan pembangunan (fkipunlam, 2013). Hal ini berarti bahwa alumni Alumni dari Fakultas Keguruan dan Ilmu Pendidikan Universitas Lambung Mangkurat 
diharapkan setelah lulus nantinya dtidak hanya menjadi tenaga guru saja, tetapi juga dapat menjadi seorang pencipta lapangan pekerjaan sesuai dengan pengembangan pembangunan.

Berdasarkan data lulusan Fakultas Keguruan dan Ilmu Pendidikan Universitas Lambung Mangkurat Banjarmasin tahun 2011, sebanyak 2.419 alumni (bpskalsel, 2012). Oleh karena itu, Fakultas Keguruan dan Ilmu Pendidikan Universitas Lambung Mangkurat harus dapat mengantisipasi lonjakan lulusan dari alumninya yang tidak dapat menjadi tenaga kependidikan dengan memberikan bekal mengenai pengetahuan kewirausahaan dalam setiap kegiatan perkuliahan yang diselenggarakannya melalui kurikulum yang telah memasukkan mata kuliah kewirausahaan. Khusus untuk program studi pendidikan ekonomi dimana alumninya diharapkan mampu mengajar mata pelajaran Kewirausahaan di Sekolah Menengah Kejuruan.

Universitas Lambung Mangkurat telah mengadakan berbagai program mahasiswa wirausaha yang merupakan kelanjutan dari program-program sebelumnya (PKM, Co$o p$, KWU, MKU, KKU, KBPK dan INWUB) untuk menjembatani para mahasiswa memasuki dunia bisnis rill melalui fasilitas start up bussines. Program tersebut diciptakan sebagai wadah agar mereka mendapatkan peluang berwirausaha dan pengalaman baru dalam berwirausaha yang nantinya akan dapat membiayai hidup sendiri, tanpa ada pembekalan terdahulu sebelum mereka membuka usaha (Setiti, 2010, p.54). Kegiatan praktik kewirausahaan yang menampung aspirasi dan pemunculan kreatifitas berwirausaha mereka belum mendukung secara maksimal. Belum lagi permasalahan pengelolaan pendanaan kegiatan kewirausahaan yang kurang profesional. Harus diberlakukan sangsi agar mahasiswa berlatih bertanggungjawab serta perlu ada kepedulian pimpinan dalam pengembangan kewirausahaan di kampus (Setiti, 2010, p.56).

Oleh karena itu perlu adanya kerjasama antara pimpinan sebagai pembuat kebijakan dan dosen sebagai pelaksana kebijakan yang benar-benar bertanggungjawab dan tidak bersifat temporary saja dalam mendukung kegiatan kewirausahaan, tentunya dalam hal ini adalah seluruh elemen civitas Universitas
Lambung Mangkurat. Diharapkan Universitas dalam lingkup besar maupun Fakultas dalam lingkup kecil, dapat memfasilitasi kegiatan yang bersifat pemunculan kreatifitas dan inovasi para mahasiswanya, serta adanya pembekalan pengetahuan yang cukup memadai. Kegiatan festival, seminar ataupun talkshow kewirausahaan sangat berperan besar terhadap penambahan pengetahuan mahasiswa.

Untuk itu diperlukan perubahan sistem pendidikan kewirausahaan yang tadinya difokuskan pada orientasi pengendalian fungsional seperti, keuangan, pemasaran, sumber daya manusia dan operasi menjadi fokus pada mengembangkan jiwa kewirausahaan pada peserta didik. Sehingga tantangannya adalah bagaimana sistem pembelajaran yang dapat mengembangkan diri peserta didik mereka dalam hal keterampilan, atribut dan sekaligus karakteristik perilaku seorang wirausaha (Bell, 2008 dalam Darpujiyanto, 2010, p.43). Sehingga dapat disimpulkan dari uraian di atas bahwa pemberian pembelajaran dalam kewirausahaan sangat diperlukan agar mereka memiliki kesiapan berwirausaha sehingga dapat mewujudkan pertumbuhan ekonomi Indonesia yang maju dimasa yang akan datang.

Penelitian ini dibatasi pada permasalahan peranan orang tua, lingkungan dan pembelajaran kewirausahaan terhadap kesiapan berwirausaha pada mahasiswa Program Studi Pendidikan Ekonomi Fakultas Keguruan dan Ilmu Pendidikan Universitas Lambung Mangkurat Banjarmasin Kalimantan Selatan.

Tujuan penelitian ini adalah memaparkan peranan pandangan orang tua, lingkungan dan pembelajaran kewirausahaan secara bersamasama terhadap kesiapan berwirausaha pada mahasiswa Program Studi Pendidikan Ekonomi Fakultas Keguruan dan Ilmu Pendidikan Universitas Lambung Mangkurat Banjarmasin Kalimantan Selatan.

Kegunaan dari penelitian ini adalah memberikan kontribusi gagasan tentang halhal yang sebaiknya dilakukan oleh orang tua dan lingkungan dalam upaya memberikan dukungan penuh agar dapat menjadi wirausaha yang sukses, dan memberikan kontribusi gagasan dalam pengembangan kurikulum 
pembelajaran kewirausahaan oleh instansi pendidikan khususnya perguruan tinggi yang memuat komponen-komponen skill atau keahlian baik itu softskill maupun hardskill dan perubahan mindset atau pola pikir bagi mahasiswanya untuk menjadi seorang wirausaha yang tangguh dan berkarakter positif.

Untuk menyatukan pemahaman dan untuk mencegah kesalahpahaman dalam penafsiran beberapa istilah maka perlu dibatasi pengertian istilah-istilah dalam penelitian ini sebagai berikut:

\section{Kesiapan Berwirausaha}

Kesiapan berwirausaha adalah suatu kondisi dimana seseorang merasa telah memiliki bekal dalam berwirausaha yang membuatnya siap dalam menghadapi situasi baik itu bersifat negatif maupun positif dalam berwirausaha. Situasi dimana memerlukan kesiapan mental dan fisik untuk memberikan respon terhadap perubahan yang terjadi dalam dunia wirausaha. Bekal yang dimaksud yaitu pengetahuan, keterampilan dan sikap/ kemampuan.

\section{Peranan Orang Tua}

Peranan orang tua adalah fungsi dari orang tua yang memberikan masukan atau pertimbangan baik berupa sudut pandang dan pola pikir berdasarkan pengetahuan yang didapat dan dimiliki mereka serta pengalaman yang memberikan pengaruh secara pribadi dalam mendukung keputusan yang diambil oleh anak.

\section{Lingkungan}

Lingkungan adalah suasana / keadaan ataupun tempat dimana terjadi interaksi sosial dan memberikan pengaruh baik itu pola pikir, pandangan dan secara langsung maupun tidak langsung terhadap perkembangan jiwa dan sikap individu. Lingkungan yang dimaksud disini ialah lingkungan keluarga terdekat, lingkungan perkuliahan, lingkungan sekitar tempat tinggal dan lingkungan kerjanya.

\section{Pembelajaran Kewirausahaan}

Pembelajaran Kewirausahaan adalah proses pemberian dan penerimaan atau penambahan pengetahuan mengenai kewirausahaan yang dilakukan dalam lingkup skala kecil yaitu dalam proses pemberian mata kuliah di perguruan tinggi ataupun kegiatan non formal. Pembelajaran kewirausahaan dapat diperoleh melalui perkuliahan, kegiatan praktik dan seminar yang diikuti lalu di implementasikan melalui kegiatan sehingga menjadikan tambahan pengalaman.

\section{METODE PENELITIAN}

\section{Jenis Penelitian}

Dalam penelitian ini pendekatan yang digunakan adalah pendekatan kuantitatif.

\section{Waktu dan Tempat Penelitian}

Penelitian ini dilaksanakan pada Program Studi Pendidikan Ekonomi Fakultas Keguruan dan Ilmu Pendidikan Universitas Lambung Mangkurat Banjarmasin Kalimantan Selatan. Waktu penelitian dilaksanakan pada bulan Januari sampai dengan Februari 2013.

\section{Target/Subjek Penelitian.}

Penelitian ini tergolong penelitian sampel karena tidak menggunakan semua mahasiswa, melainkan dengan mengambil sampel penelitian sesuai dengan ketentuan pengambilan sampel pada Tabel penentuan jumlah sampel dari populasi tertentu dengan taraf kesalahan $5 \%$ oleh Isaac dan Michael (Sugiyono, 2009, p. 86). Teknik sampling yang digunakan adalah proportional random sampling.

Populasi dalam penelitian ini adalah mahasiswa pengambil mata kuliah Kewirausahaan Program Studi Pendidikan Ekonomi Fakultas Keguruan dan Ilmu Pendidikan Universitas Lambung Mangkurat Banjarmasin Kalimantan Selatan sebanyak 162 mahasiswa. Sedangkan sampel dalam penelitian ini adalah mahasiswa angkatan 2010 dan 2011 sejumlah 110 mahasiswa kelas Reguler dan Mandiri pengambil mata kuliah Kewirausahaan Program Studi Pendidikan Ekonomi Fakultas Keguruan dan Ilmu Pendidikan Universitas Lambung Mangkurat Banjarmasin. 
Tabel 1. Kategori kecenderungan peranan orang tua

\begin{tabular}{clccc}
\hline No & Kategori & Interval & Frekuensi & Frekuensi kumulatif \\
\hline 1 & Tinggi & $>60$ & 4 & 4 \\
2 & Cukup & $45-59$ & 93 & 97 \\
3 & Kurang & $30-44$ & 13 & 110 \\
4 & Rendah & $<30$ & 0 & 110 \\
\multicolumn{2}{c}{ Total } & & 110 & \\
\hline
\end{tabular}

Sumber: data primer yang diolah

Tabel 2. Kategori kecenderungan lingkungan

\begin{tabular}{clccc}
\hline No & Kategori & Interval & Frekuensi & Frekuensi kumulatif \\
\hline 1 & Tinggi & $>60$ & 28 & 28 \\
2 & Cukup & $45-60$ & 82 & 110 \\
3 & Kurang & $30-44$ & 0 & 110 \\
4 & Rendah & $<30$ & 0 & 110 \\
\multicolumn{2}{l}{ Total } & & 110 & \\
\hline
\end{tabular}

Sumber: data primer yang diolah

\section{Prosedur}

Proses sampling yang dilakukan diawali dengan cara menentukan sampel yang digunakan dalam penelitian, di mana dalam hal ini peneliti menggunakan 2 angkatan pada program studi Pendidikan Ekonomi Fakultas Keguruan dan Ilmu Pendidikan. Selanjutnya penentuan jumlah sampel dihitung menggunakan rumus Slovin, rumus Taro Yamane, rumus Krejcie-Morgan. Hasil perhitungan dari berbagai rumus tersebut sebagai penguatan pengambilan keputusan menggunakan tabel yang dijelaskan oleh Isaac dan Michel.

\section{Teknik Analisis Data}

Penelitian ini dilakukan menggunakan pengumpulan data dengan metode angket. Data yang terkumpul ditabulasi dan selanjutnya dilakukan uji asumsi klasik untuk mengetahui apakah datanya bias, linear dan unbias. Kemudian data dianalisis menggunakan teknik regresi linear berganda. Statistik deskriptif digunakan untuk menghitung rata-rata $(\mathrm{M})$, Simpangan Baku (SD), Modus (Mo), dan Median (Me). Sebelum dilakukan analisis data, untuk pengujian hipotesis terlebih dahulu dilakukan uji persyarat analisis terhadap data penelitian, yaitu uji normalitas, uji linearitas dan uji multikolinearitas.

\section{HASIL PENELITIAN DAN PEMBAHASAN}

Hasil dari penelitian peranan orang tua, lingkungan dan pembelajaran kewirausahaan terhadap kesiapan berwirausaha mahasiswa Program Studi Pendidikan Ekonomi Fakultas Keguruan dan Ilmu Pendidikan Universitas Lambung Mangkurat Banjarmasin Kalimantan Selatan dapat dilihat pada tabel 1.

Berdasarkan tabel 1, dapat diketahui variabel peranan orang tua pada kategori tinggi sebanyak 4 mahasiswa, kategori cukup sebanyak 93 mahasiswa, kategori kurang sebanyak 13 mahasiswa dan kategori rendah sebanyak 0 mahasiswa. Hal ini menunjukkan bahwa peranan orang tua cukup memiliki pengaruh terhadap kesiapan berwirausaha mahasiswa, terbukti sebanyak 93 mahasiswa menjawab cukup berpengaruh.

Pengaruh yang dimaksud adalah pengaruh positif maupun negatif yang diberikan oleh orang tua mengenai berwirausaha. Pengaruh positif terjadi ketika orang tua mendukung anaknya untuk mengambil keputusan apapun itu, termasuk dalam mengambil keputusan 
Tabel 3. Kategori kecenderungan pembelajaran kewirausahaan

\begin{tabular}{clccc}
\hline No & Kategori & Interval & Frekuensi & Frekuensi kumulatif \\
\hline 1 & Tinggi & $>64,5$ & 9 & 9 \\
2 & Cukup & $48-64,5$ & 101 & 110 \\
3 & Kurang & $31,5-47,5$ & 0 & 110 \\
4 & Rendah & $<31,5$ & 0 & 110 \\
\multicolumn{2}{l}{ Total } & & 110 & \\
\hline
\end{tabular}

Sumber: data primer yang diolah

Tabel 4. Kategori kecenderungan kesiapan berwirausaha

\begin{tabular}{clccc}
\hline No & Kategori & Interval & Frekuensi & Frekuensi kumulatif \\
\hline 1 & Tinggi & $>55,5$ & 38 & 38 \\
2 & Cukup & $42-55,5$ & 71 & 109 \\
3 & Kurang & $28,5-41,5$ & 1 & 110 \\
4 & Rendah & $<28,5$ & 0 & 110 \\
\multicolumn{2}{c}{ Total } & & 110 & \\
\hline
\end{tabular}

Sumber: data primer yang diolah

untuk menjadi seorang wirausaha. Dan pengaruh negatif terjadi ketika orang tua tidak menyetujui anaknya menjadi seorang wirausaha, dikarenakan pengetahuan yang terbatas mengenai kewirausahaan, pengalaman yang buruk dan latar belakang keluarga yang tidak terbuka mengenai wirausaha.

Berdasarkan tabel 2, dapat diketahui variabel lingkungan pada kategori tinggi sebanyak 28 mahasiswa, kategori cukup sebanyak 82 mahasiswa, kategori kurang sebanyak 0 mahasiswa dan kategori rendah sebanyak 0 mahasiswa. Hal ini menunjukkan bahwa lingkungan cukup memiliki pengaruh terhadap kesiapan berwirausaha mahasiswa, terbukti sebanyak 82 mahasiswa menjawab cukup berpengaruh. Pengaruh yang dimaksud adalah lingkungan yang positif, kondusif dan mendukung mahasiswa dalam menyalurkan bakat kewirausahaannya.

Berdasarkan tabel 3 dapat diketahui variabel pembelajaran kewirausahaan pada kategori tinggi sebanyak 9 mahasiswa, kategori cukup sebanyak 101 mahasiswa, kategori kurang sebanyak 0 mahasiswa dan kategori rendah sebanyak 0 mahasiswa.
Hal ini menunjukkan bahwa pembelajaran kewirausahaan cukup memiliki pengaruh terhadap kesiapan berwirausaha mahasiswa, terbukti sebanyak 101 mahasiswa menjawab cukup berpengaruh. Mahasiswa mengganggap bahwa pembelajaran mengenai kewirausahaan memberikan gambaran dan membuka ide-ide dalam berwirausaha sehingga mahasiswa dapat berinovasi dan menciptakan kreatifitas yang tidak terbatas. Dan hal tersebut berpengaruh positif bagi mereka.

Berdasarkan tabel 4 dapat diketahui variabel kesiapan berwirausaha pada kategori tinggi sebanyak 38 mahasiswa, kategori cukup sebanyak 71 mahasiswa, kategori kurang sebanyak 1 mahasiswa dan kategori rendah sebanyak 0 mahasiswa.

Hal ini menunjukkan bahwa setelah mendapat dukungan yang positif, lingkungan yang mendukung, dan pembelajaran kewirausahaan cukup memiliki pengaruh terhadap kesiapan berwirausaha mahasiswa apabila mereka lulus nantinya, terbukti sebanyak 71 mahasiswa menjawab hal tersebut diatas dirasa cukup berpengaruh terhadap kesiapan mereka nantinya setelah lulus kuliah. 


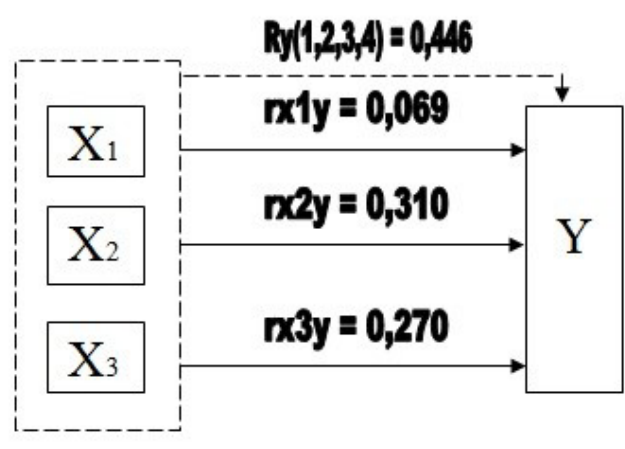

Gambar 1: Paradigma Hasil Penelitian

Gambar 1. Paradigma hasil penelitian

\section{Pengaruh peranan orang tua terhadap kesiapan berwirausaha}

Hasil pengujian hipotesis pertama dari penelitian ini adalah tidak terdapat pengaruh signifikan antara peranan orang tua terhadap kesiapan berwirausaha mahasiswa. Hal ini dibuktikan dari hasil regresi linier variabel peranan orang tua (X1) terhadap kesiapan berwirausaha (Y) menunjukkan nilai signifikansi $\mathrm{p}=0,339$ atau lebih besar dari tingkat alpha 0,05 . Selain itu diperoleh nilai koefesien korelasi parsial Rpar $=0,093$, koefesien determinasi Rsquare $=0,069$, yang mengidentifikasikan terdapat sumbangan pengaruh variabel peranan orang tua terhadap kesiapan berwirausaha sebesar $6,9 \%$.

Dari hasil analisis menunjukkan bahwa peranan orang tua tidak berpengaruh secara signifikan terhadap kesiapan berwirausaha mahasiswa di Banjarmasin Kalimantan Selatan. Orang tua memiliki peranan penting terhadap anak. Orang tua memberikan dukungan kepada anak-anak khususnya dalam hal mencukupi kebutuhan-kebutuhan seperti pendidikan, kesehatan, sandang, dll. Pola asuh dari orang tua dan pendidikan yang terjadi dalam keluarga merupakan salah satu bagian terpenting dalam pembentukan karakter bagi mahasiswa.

Bagi kebanyakan orang tua, wirausaha usaha tidak berbeda dari pedagang. Memiliki pekerjaan yang tetap seperti menjadi pegawai negeri sipil atau bekerja diperusahaan swasta menjadi pilihan yang lebih baik. Pengalaman yang buruk dan pengetahuan yang terbatas mengenai wirausaha juga menjadikan para orang tua bersikap skeptis.
Akan tetapi orang tua yang berprofesi sebagai wirausaha diyakini dapat menjadi panutan (entrepreneurial role model) yang akan membentuk minat anak untuk berwirausaha di masa depan (Dunn \& HoltzEakin, 2000; Galloway et al., 2006, Suharti \& Sirine, 2012, p.131). Penelitian ini mendukung berbagai temuan studi di atas dengan diterimanya hipotesis bahwa mahasiswa yang memiliki orangtua dengan latar belakang pekerjaan wirausaha memiliki memiliki niat kewirausahaan yang lebih tinggi.

Pengaruh keluarga, pendidikan dan pengalaman kerja pertama adalah faktor penting dalam pengembangan karir (Farzier \& Niehm, 2008 dalam Sondari, 2011, p.6). Orang tua memberikan dampak kuat pada pemilihan karir, penelitian menunjukkan para wirausaha biasanya memiliki orang tua yang juga seorang wirausaha.

Naffziger et all dalam Muhadi (2005, p.18) mengatakan bahwa banyak individu sejak dini dididik dan dimotivasi untuk menjadikan karir pendahulu (orang tua) sebagai pilihan karirnya di masa mendatang. Mengingat hal demikian, sangat mungkin sejak dini dalam diri anak terbentuk konsepsi-konsepsi nilai yang mengakar dalam jiwa mereka (Koentjaraningrat dalam Muhadi, 2005, p.18).

Anak yang berasal dari latar belakang pekerjaan orang tua yang bukan seorang wirausaha sangat mungkin untuk tidak menjadi seorang wirausaha juga. Tetapi walaupun demikian, lingkungan yang membuat anak merasa lebih nyaman untuk berwirausaha, yang menjadikan mereka bisa kreatif dan inovatif dan pengetahuan yang selalu berproses dalam kehidupan anak, menjadikan anak lebih terbuka dan menerima masukan-masukan yang dianggap positifmengenai wirausaha walaupun akhirnya pendapat dan keputusan mereka bertolakbelakang dengan pandangan dan masukan yang diberikan orang tua. Sehingga menjadikan mereka tetap berpendirian untuk menjadi seorang wirausaha.

\section{Pengaruh lingkungan terhadap kesiapan berwirausaha}

Hasil pengujian hipotesis kedua dari penelitian ini adalah terdapat pengaruh 
signifikan antara lingkungan terhadap kesiapan berwirausaha mahasiswa. Hal ini dibuktikan dari hasil analisa linier variabel lingkungan (X2) terhadap kesiapan berwirausaha (Y) menunjukkan nilai signifikansi $\mathrm{p}=0,000$ atau lebih kecil dari tingkat alpha 0,05 . Selain itu diperoleh nilai koefesien korelasi parsial Rpar $=0,385$, koefesien determinasi Rsquare $=0,310$, yang mengidentifikasikan terdapat sumbangan pengaruh variabel lingkungan terhadap kesiapan berwirausaha sebesar $31 \%$.

Dari hasil penelitian menyatakan bahwa nilai yang ditanamkan oleh masingmasing lingkungan, dalam hal ini lingkungan keluarga, kepada anak-anaknya memiliki ciri yang berbeda. Lingkungan keluarga merupakan lingkungan awal yang membentuk kepribadian mahasiswa. Begitu juga pada proses pengenalan kewirausahaan pada mahasiswa di lingkungan keluarga. Seperti yang dijelaskan oleh Soemanto (2006, p.95) bahwa "pendidikan manusia wirausaha harus dimulai sejak manusia masih mulai hidup dan berkembang di lingkungan rumah tangga atau keluarga. Disinilah letak pengaruh orang tua dan keluarga di dalam mepersiapkan manusia wirausaha". Semakin tinggi intesitas keluarga dari mahasiswa mengenalkan kewirausahaan pada mahasiswa, maka mahasiswa tersebut akan memiliki tingkat kesiapan untuk berwirausaha semakin tinggi pula.

Lingkungan sekitar anak juga berpengaruh pada kreatifitas dan pola pikir sebagai seorang wirausaha. Lingkungan sosial merupakan lingkungan di mana terjadi antara individu yang satu dengan yang lain. Lingkungan sosial ini ada yang primer dan ada yang sekunder. Lingkungan primer terjadi bila di antara individu yang satu dengan yang lain mempunyai hubungan yang erat dan saling mengenal dengan baik, misalnya keluarga. Lingkungan demikian akan mempunyai pengaruh yang mendalam terhadap perkembangan individu. Lingkungan sosial sekunder adalah suatu lingkungan di mana antara individu yang ada di dalamnya mempunyai hubungan dengan individu lainnya, pengaruh lingkungan ini relatif tidak mendalam.

Lingkungan dalam hal ini adalah lingkungan sosial, ialah semua yang orang/ manusia lain yang mempengaruhi kita (Purwanto, 2006, p. 28). Pengaruh lingkungan sosial itu ada yang kita terima secara langsung dan ada yang tidak langsung. Pengaruh secara langsung, seperti dalam pergaulan seharihari dengan orang lain, dengan keluarga kita, teman-teman kita, kawan sekolah, sepekerjaan dan sebagainya. Yang tidak langsung, melalui radio dan televisi, dengan membaca bukubuku, majalah-majalah, surat-surat kabar, dan sebagainya, dan dengan cara yang lain.

Sikap masyarakat mempunyai pengaruh potensial dalam mendorong atau menghambat pola perilaku kewirausahaan. Seorang wirausahawan tidak merasa leluasa bergerak dan bertindak, jika ia berada ditengah-tengah anggota masyarakat yang memiliki pandangan negatif terhadap kegiatan wirausaha.

Dari pembahasan di atas, diharapkan pengaruh lingkungan dari mahasiswa agar dapat lebih mendukung kewirausahaan sejak dini.

\section{Pengaruh pembelajaran kewirausahaan terhadap kesiapan berwirausaha}

Hasil pengujian hipotesis ketiga dari penelitian ini adalah terdapat pengaruh signifikan pembelajaran kewirausahaan terhadap kesiapan berwirausaha mahasiswa. Hal ini dibuktikan dari hasil analisa linier variabel pembelajaran kewirausahaan (X3) terhadap kesiapan berwirausaha (Y) menunjukkan nilai signifikansi $\mathrm{p}=0,000$ atau lebih kecil dari tingkat alpha 0,05. Selain itu diperoleh nilai koefesien korelasi parsial Rpar $=0,342$, koefesien determinasi Rsquare $=0,270$, yang mengidentifikasikan terdapat sumbangan pengaruh variabel lingkungan terhadap kesiapan berwirausaha sebesar $27 \%$.

Proses pembelajaran kewirausahaan mencakup pemberian keterampilan-keterampilan luas yang dapat ditularkan, pembentukan/ pengembangan pribadi, dan mengasah kemampuan untuk membuat perencanaan yang inovatif bagi peserta didik (Brown, dalam Muhadi, 2005, p.19). Hal ini berarti aspekaspek pembelajaran mengenai kewirausahaan harus betul-betul diperhatikan.

Pembelajaran kewirausahaan bukan hanya didapatkan dari pengalaman saja, tetapi 
tetap melalui proses pendidikan karena dua hal tersebut adalah sesuatu yang tidak dapat dipisahkan. Rae (2000) dalam Priyanto (2009, p.65) menggambarkan bahwa pengembangan kemampuan wirausaha dipengaruhi oleh motivasi, nilai-nilai individu, kemampuan, pembelajaran, hubungan-hubungan, dan sasaran yang diinginkannya. Sementara itu Minniti dan Bygrave (2001) dalam Priyanto (2009, p.65) membuktikan dalam model dinamis pembelajaran wirausaha, bahwa kegagalan dan keberhasilan wirausaha akan memperkaya dan memperbaharui stock of knowledge serta sikap wirausaha sehingga ia menjadi lebih mampu dalam berwirausaha.

Karenanya pola dasar pembelajaran kewirausahaan harus sistemik, yang didalamnya memuat aspek-aspek teori, praktik, dan implementasi. Desain pembelajaran yang diberikan adalah pembelajaran yang berorientasi atau diarahkan untuk menghasilkan business entrepreneur terutama yang menjadi owner entrepreneur atau calon wirausaha mandiri yang mampu mendirikan, memiliki dan mengelola perusahaan serta dapat memasuki dunia bisnis dan dunia industri secara profesional. Karenanya pola dasar pembelajaran harus sistemik, yang di dalamnya memuat aspek-aspek teori, praktek dan implementasi. Di samping itu dalam pelaksanaan pembelajaran hendaknya disertai operasionalisasi pendidikan yang relatif utuh menyeluruh seperti pelatihan, bimbingan, pembinaan, konsultasi dan sebagainya.

\section{Pengaruh peranan orang tua, lingkungan, dan pembelajaran kewirausahaan secara bersama-sama terhadap kesiapan ber- wirausaha}

Hasil pengujian hipotesis keempat dari penelitian ini adalah terdapat pengaruh signifikan antara peranan orang tua, lingkungan, dan pembelajaran kewirausahaan secara bersama-sama terhadap kesiapan berwirausaha mahasiswa. Hal ini dibuktikan dari hasil analisa regresi linear ganda dengan bantuan program PASW 18,0 menunjukkan bahwa $\mathrm{R} Y, X_{1}, X_{2} X_{3}$ sebesar 0,669 , keberartian regresi ganda diuji dengan mencari harga $\mathrm{F}$ hitung sebesar 28,695 dan harga $F$ tabel pada taraf signifikansi $5 \%$ sebesar 2,45, F hitung lebih besar dari $\mathrm{F}$ tabel $(28,695>2,45)$ sehingga terjadi pengaruh yang signifikan. Signifikansi juga ditunjukkan dengan adanya $\mathrm{p}<0,05$, dimana $\mathrm{p}$ hitung yang diperoleh yaitu 0,000 , maka $0,000<0,05$, dan hipotesis keempat diterima. Hal ini menunjukkan bahwa terdapat pengaruh signifikan antara peranan orang tua, lingkungan, dan pembelajaran kewirausahaan secara bersama-sama terhadap kesiapan berwirausaha mahasiswa. Selain itu diperoleh nilai Rsquare 0,448 yang mengidentifikasikan bahwa variabel bebas yang digunakan dalam penelitian ini memberikan pengaruh terhadap kesiapan berwirausaha mahasiswa sebesar $44,8 \%$, sedangkan sisanya dipengaruhi oleh variabel lain yang tidak diungkapkan dalam penelitian ini.

Berdasarkan hasil data statistik tersebut dapat disimpulkan adanya pengaruh signifikan antara peranan orang tua, lingkungan, dan pembelajaran kewirausahaan secara bersamasama terhadap kesiapan berwirausaha mahasiswa. Hal ini menunjukkan bahwa kesiapan berwirausaha mahasiswa merupakan suatu hal yang tidak muncul begitu saja, tetapi didukung oleh berbagai faktor, diantaranya adalah orang tua, lingkungan, dan pembelajaran mengenai kewirausahaan. Seperti yang telah diungkapkan melalui variabel bebas dalam penelitian ini adalah sebagian kecil dari berbagai faktor yang mendukung dan membentuk kesiapan berwirausaha mahasiswa.

Variabel peranan orang tua dalam hal ini menunjukkan sejauh mana pengaruh orang tua terhadap proses kesiapan wirausaha mahasiswa. Ketidaktahuan, pengalaman buruk dan pendapat orang lain tentang wirausaha menjadikan orang tua bersikap skeptis terhadap wirausaha. Walaupun variabel peranan orang tua tidak berkorelasi tetapi mempunyai pengaruh juga secara bersama-sama terhadap kesiapan berwirausaha.

Seiring dengan proses waktu, informasi yang didapat dari berbagai media menjadikan para orang tua mulai terbuka akan berwirausaha. Sehingga pandangan negatif orang tua akan berwirausaha berangsur-angsur berubah menjadi positif. Pada variabel lingkungan, situasi lingkungan yang kondusif dan mendukung kesiapan berwirausaha mahasiswa 
menjadikan mahasiswa merasa dapat menjadi kreatif dan inovatif, berani mengambil keputusan dan resiko, dan menjadikan mereka percaya diri dan bermental tangguh sebagai seorang wirausaha.

Selain dua faktor tersebut, variabel pembelajaran mengenai wirausaha membantu mereka membuka wawasan yang sesungguhnya mengenai wirausaha. Semakin banyak pengetahuan mereka mengenai wirausaha, menjadikan mereka termotivasi untuk mencoba menyalurkan ide-ide wirausaha yang baru dan membangun.

Berdasarkan pembahasan tersebut di atas, bahwa tiap-tiap variabel memberikan kontribusi yang positif pada kesiapan berwirausaha mahasiswa. Hal yang sama tentunya juga akan berlaku apabila tiap-tiap variabel tersebut ditinjau secara bersama-sama terhadap kesiapan berwirausaha mahasiswa. Dimana hal ini juga dibuktikan berdasarkan hasil olah data statistik dari program PASW 18,0 menunjukkan kontribusi sebesar 44,8 \% terhadap kesiapan berwirausaha mahasiswa dari semua variabel bebas yang diajukan secara bersama-sama.

\section{SIMPULAN DAN SARAN}

\section{Simpulan}

Berdasarkan analisis data dan pembahasan hasil penelitian, maka dapat dirumuskan kesimpulan bahwa peranan orang tua tidak berpengaruh secara signifikan terhadap kesiapan berwirausaha mahasiswa Prodi Pendidikan Ekonomi Fakultas Keguruan dan Ilmu Pendidikan Universitas Lambung Mangkurat Banjarmasin Kalimantan Selatan, dan secara umum memiliki kategori cukup. Sedangkan lingkungan dan pembelajaran kewirausahaan memiliki pengaruh signifikan terhadap kesiapan berwirausaha mahasiswa Prodi Pendidikan Ekonomi Fakultas Keguruan dan Ilmu Pendidikan Universitas Lambung Mangkurat Banjarmasin Kalimantan Selatan, dan secara umum memiliki kategori cukup.

Kemudian peranan orang tua, lingkungan dan pembelajaran kewirausahaan secara bersama-sama memiliki pengaruh signifikan terhadap kesiapan berwirausaha mahasiswa
Program Studi Pendidikan Ekonomi Fakultas Keguruan dan Ilmu Pendidikan Universitas Lambung Mangkurat Banjarmasin Kalimantan Selatan, dan secara umum memiliki kategori cukup.

\section{Saran}

Berdasarkan hasil penelitian yang diperoleh, maka dapat diajukan beberapa saran untuk meningkatkan kesiapan berwirausaha mahasiswa Program studi Pendidikan Ekonomi Fakultas Keguruan dan Ilmu Pendidikan Universitas Lambung Mangkurat Banjarmasin Kalimantan Selatan, sebagai berikut:

1. Bagi mahasiswa:

a. Mahasiswa hendaknya dapat memberikan pandangan mengenai konsep kewirausahaan yang sebenarnya kepada orang tua mereka. Kewirausahaan bukan hanya semata-mata mengenai untung dan rugi, tetapi bagaimana menjadikan seorang mahasiswa dapat lebih kreatif dan inovatif, memiliki sikap-sikap unggul, berani menghadapi tantangan dan menjadi insan yang selalu bekerja keras serta jujur.

b. Mahasiswa hendaknya dapat mengambil hal-hal positif dan menangkap peluang dari lingkungan mereka untuk menciptakan sebuah inovasi baru dalam berwirausaha.

c. Mahasiswa hendaknya selalu menyadari bahwa pembelajaran kewirausahaan tidak hanya didapatkan dari bangku perkuliahan saja, tetapi secara global dapat didapatkan dari keadaan sekitarnya.

2. Bagi Dosen:

Hendaknya dosen dan para pendidik yang lain dapat lebih inovatif lagi dalam menciptakan pembelajaran yang menyenangkan dan tidak bersifat teori sehingga mahasiswa dapat berkembang secara utuh dalam berwirausaha

3. Bagi Instansi Pendidikan:

Hendaknya Instansi Pendidikan yang bersangkutan dapat mengembangkan pembelajaran kewirausahaan dengan menyediakan sarana dan prasarana yang menunjang dan menciptakan suasana belajar yang menyenangkan. 


\section{DAFTAR PUSTAKA}

Badan Pusat Statistik. (2012). Pada Februari 2012, tingkat pengangguran terbuka 6.32 persen. Diakses tanggal 30 Juli 2012 dari http:// www. bps.go.id /?news $=928$

Badan Pusat Statistik Kalimantan Selatan. (2012). Jumlah pegawai negeri sipil kalimantan selatan tahun 2012, tingkat pengangguran terbuka 6.32 persen. Diakses tanggal 30 Juli 2012 dari http:// www.kalsel.bps.go.id/?news $=928$

Calhoun, C. C. \& Finch, A. V. (1982). Vocational education: concepts and operations. California: Wadsworth publishing company.

Darpujiyanto. (2010). Pembelajaran yang menumbuhkan minat mahasiswa berwirausaha. Jurnal Ilmiah Bisnis dan Ekonomi ASIA Vol. 5 No. 1. Desember 2010. Diakses tanggal 15 Nopember 2012 dari http://www.scribd.com/ document_downloads/direct/82223211? extension $=$ pdf\& $\mathrm{ft}=1351811495 \& \mathrm{lt}=135$ $1815105 \&$ source $=$ read + page $\& u a h k=q T$ PcuhioQu0kSxnw8ADpI14ES54

Departemen Keuangan Republik Indonesia. (2013). Rencana pembangunan menengah 2010-2014. Jakarta: Depkeu.

Fakultas Keguruan dan Ilmu Pendidikan. 2013. Visi Misi FKIP Unlam. Diakses tanggal 24 Oktober 2013 Dari http://fkipunlam. ac.id

Kementerian Koperasi dan Usaha Kecil dan Menengah. (2012). Bangun wirausaha idealnya $\mathrm{Rp} 5$ miliar per tiap tahun. Diakses tanggal 30 Juli 2012, dari http:// epaper.danabergulir.com/wp-content/ uploads/2012/04/Edisi-4-April-2012. pdf
Kementerian Pendidikan dan Kebudayaan. (2011). Data tenaga keguruan tahun 2011. Diakses tanggal 6 Nopember 2012 dari http://www.jpnn.com

Purwanto, N. (2006). Psikologi pendidikan. Bandung: PT. Remaja Rosdakarya.

Priyanto, S. H. (2009). Mengembangkan pendidikan kewirausahaan di masyarakat. Jurnal Ilmiah Pendidikan Formal Dan Informal. Volume 1 / No 1 - Nopember 2009. Diakses tanggal 30 Juli 2012 dari http://andragogia. p2pnfisemarang.org/wp-content/ uploads/2010/11/ andragogia1_4.pdf.

Sugiyono. (2009). Metode penelitian kuantitatif dan R\&D. Bandung: Alphabeta.

Suharti, L. \& Sirine, H. (2012). Faktorfaktor yang berpengaruh terhadap niat kewirausahaan (entrepreneurial intention). (studi terhadap mahasiswa Universitas Kristen Satya Wacana, Salatiga). Jurnal Manajemen dan Kewirausahaan. Vol 13, No 2 September 2011 Diakses tanggal 4 Januari 2013 dari http://puslit2.petra.ac.id/ejournal/index. $\mathrm{php} / \mathrm{man} /$ article/viewFile/18329/18174

Unesco. (1973). Technical and vocational teacher education and training. Paris: United Nations Educational. 